\title{
The International
}

\section{and \\ Comparative Law Quarterly}

\section{VOLUME 25}

1976

William S. Hein \& Co., Inc.

Buffalo, New York

2003 
(6) British Institute of International and Comparative Law 1976.

Published by Oxford University Press.

All rights reserved

This book has been digitally archived, to maintain the quality of the original work for future generations of legal researchers, by William S. Hein \& Co., Inc.

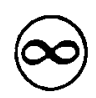

This volume is printed on acid-free paper by William S. Hein \& Co., Inc. 


\title{
The International and Comparative Law Quarterly
}

\author{
BOARD OF EDITORS \\ General Editor \\ K. R. SIMMONDS \\ Assistant General Editor \\ TOM HARPER
}

P. B. CARTER

A. K. R. Kiralfy

NORMAN S. MarSh, Q.C.

Contributions to the International and Comparative Law Quarterly express the view's of their authors and not necessarily the views of the Editorial Board or of the British Institute of International and Comparative Law. 


\title{
The British Institute of International and Comparative Law
}

\author{
COUNCIL OF MANAGEMENT
}

Chairman: THE RT. HON. LORD DENNiNG, M.R.

Vice-Chairman: M. E. Bathurst, C.M.G., C.B.E., Q.C., D.C.L, LL.D.

Professor Sir Norman Anderson, O.B.E., Q.C., D.D., LL.D., F.B.A.

N. Fox Bassett

The Rt. Hon. Lord Cross of Chelsea

L. A. Ellwood

Sir Vincent Evans, K.C.M.G., M.B.E., Q.C.

Sir Gerald Fitzmaurice, G.C.M.G., Q.C.

Professor R. H. Graveson, C.B.E., Q.C., LL.D.

Professor C. J. Hamson, Q.C.

Master I. H. Jacob

Professor R. Y. Jennings, Q.C.

The Hon. Mr. Justice Kerr

- The Rt. Hon. Chief Justice Bora Laskin

F. H. Lawson, D.C.L., F.B.A.

R. A. Lynex
* Professor R. St. J. Macdonald, Q.C.

Sir James McPetrie, K.C.M.G., O.B.E.

F. A. Mann, LL.D., Dr.Jur., F.B.A.

Norman S. Marsh, Q.C.

Andrew Martin, Q.C.

The Rt. Hon. Lord Justice Scarman, o.B.E.

The Rt. Hon. Lord Shawcross, G.B.E, Q.C.

Professor T. B. Smith, Q.C., D.C.L, LL.D., F.B.A.

Professor Sir Francis Vallat, K.C.M.G., Q.C.

Sir Humphrey Waldock, C.M.G., O.B.E., Q.C., D.C.L.

E. H. Wall, T.D.

The R. Hon. Lord Wilberforce, C.M.G., O.B.E.

G. G. Williams

* Commonwealth Member

ADVISORY BOARD

Public International Law Section

Chairman: SIR Gerald FITZMAURICE, G.C.M.G., Q.C.

Private International Law Section

Chairman: THE RT. HON. LORD JUSTICE SCARMAN, O.B.e.

Comparative Law Section

Chairman: THE RT. HON. LORD CROSS OF CHELSEA

DIRECTOR

Professor K. R. SimmondS 


\section{TABLE OF CONTENTS}

(An alphabetical Index of Contributors, a Subject Index, an Index of Cases Noted and an Index of Book Reviews and Books Received will be found at pp. 935 et seq.)

\section{ARTICLES}

The Baltic Conventions

Bo Johnson 1

Decisions Addressed to Member States and Article 173 of THE TREATY OF ROME

C. S. P. Harding 15

Contractual and Non-Contractual Obligations-EeC PrelimiNary Draft Convention Lawrence Collins

Regional Economic Organisations-African Experience

M. A. Ajomo 58

Collective human Rights of Peoples and Minorities

Y. Dinstein 102

War and Peace in the Conflict of Laws

R. J. Traynor 121

The Illegitimate Child in Soviet Law

Ivo Lapenna 156

Civil Liability of Physicians and New Methods of Treatment AND EXPERIMENTATION

Dieter Giesen 180

LAW Reform Now-A Comparative View

John Farrar 214

The International Protection of Human Rights-Ritual and REALTYY

T. E. MCCarthy 261

Human Rights in the United Kingdom-International StanDARDS

William Dale

The Draft EeC Bankruptcy Convention-A Further ExaminaTION

Muir Hunter 310

Privileges and Immunities of the Diplomatic Family

P. J. O'Keefe 329

Credentials of Deleontions and Representation of Member States at the United Nations

Dan Ciobanu

Social Welfare and the One-Parent family in Germany and BRITAIN

L. Müller-Fembeck and A. I. Ogus

Responsibility of the Law in Relation to Family Stability Marylyn M. Mayo

Recent Changes in Nigerian Nationality and Citizenship Law E. I. Nwogugu 


\section{ARTICLES-continued}

Hyde v. Hyde-A ReApPRaisal

Sebastian Poulter

STATE RESPONSIBILITY IN INTERNATIONAL LaW and TRansboundary POLLUTION INJURIES

Kenneth B. Hoffman

Comparative Aspects of Prorogation and Arbitration AoreeMENTS

Michael Pryles

Loss of Jobs in Strikes-The Position in England and Canada COMPARED

Geoff England

Company Structure and Employee Participation in the EECTHe BRITISH ATtitude Clive M. Schmitthoff

Employees' Rights in Mergers and Takeovers-EEC Proposals AND THE AMERICAN APPROACH

Mary Ann S. Barilett

Organs of State in Romania

Daniel N. Nelson

The Domestic Jurisdiction of States in the Practice of the United Nations and Regional Organisations

A. A. C. Trindade 715

The Berlin Agreement of 1971: Has it Worked?

Marc Carudal 766

Equity and General Principles of Law

M. Akehurst 801

The Guest-Plaintiff, the Code Civil and the Cour de CassaTION

Philip Britton 826

CONTEMPORARy CONSTITUTIONALISM and LEgal Relationships BETWEEN INDIVIDUALS

M. J. Horan 848

ISSUE ESTOPPEL BY FOREIGN JUDOMENT IN ISRAEII LAW

C. I. Goldwater 869

Delictual Liability in Scottish Private International Law

J. M. Thomson

\section{SHORTER ARTICLES, COMMENTS AND NOTES}

Polygamy and the Crime of Bigamy

Two Recent Australian Custody Cases

Combined Transport-A Further Modification

Enforcement of Foreign Judgments-Jurisdiction

Reform of the Law of Domicile in Australia

International Commodity Agreements

C. G. J. Morse

A. Bates

o. C. Giles

of Foreign Court

G. Solomons

P. E. Nygh

Richard N. Gariepy

to Some Legislative

A. H. Angelo 894

Family Law Reform in Ireland-Some Comparative Aspects

William Binchy 901

Where is the Lex Loci Divortii?

E. M. Clare Canton. 909 


\section{CURRENT LEGAL DEVELOPMENTS}

International Economic Co-operation: West Africa; Marine Pollution: Dumping; Migrant Workers: International Labour Organisation; Company Law: European Communities; Conflict of Law's: England and Wales; Contract: Great Britain; Marriage: Austria; Freedom of Expression: Sweden; Nationality: Luxembourg

International Commodity Agreemenis: Coffee, Tin and Cocoa; International Court: Western Sahara; Conservation: Unesco; Sovereign Immunity: Trading Activities; Private International Law: Hague Conventions; European Community Law: Lome Convention; European Court of Human Rights: Trade Union Rights; Patents: European Communities; Family Law: Council of Europe; Family Law: Australia; Human Rights: Sweden; Legal Profession: United Kingdom; Police Complaints: Australia

Law of the Sea: Exclusive Economic Zone; Marine Pollution: Mediterranean Sea; European Court of Human Rights: Trade Union Rights; Sex Discrimination: European Communities; United Kingdom: Law of Conspiracy

Environmental Law: European Communities; Transfrontier Pollution: OECD; Company Law: European Communities; Multinational Enterprises: OECD; Securities Trading: European Communities; Trade Marks: European Communities; Arctic: Wildlife Convention; Apartheid: United Nations; Human Rights: Sweden

BOOK REVIEWS

$247,459,696,924$

BOOKS RECEIVED

$257,471,711,930$

INDEX FOR VOLUME 25

Contributors of Articles, Shorter Articles, Comments and Notes

Subject Index

Index of Cases Noted

Index of Book Reviews and Books Received 